\title{
Evolution of some Mediterranean landscapes of Central Italy from historical aerial photographs
}

\author{
Maria Nicolina Ripa, Francesco Ciapanna, Goffredo Filibeck, Federica Gobattoni, \\ Antonio Leone, Raffaele Pelorosso, Matteo Piccinno, Carlo Maria Rossi, Fabio Recanatesi \\ Dipartimento di scienze e tecnologie per l'agricoltura, le foreste, la natura e l'energia (DAFNE), \\ University of Tuscia, Viterbo, Italy
}

\begin{abstract}
Aerial photos represent the main existent database providing evidence of landscape changes with high detail. The analysis of land cover changes plays a key role in understanding a great variety of phenomena in several research fields. Landscapes are made by society and reflect the changing society and attitude towards the environment. The reorientation of farming system, the practical results of planning processes, the rate and magnitude of the changes in the landscape are some of the most important factors relating to the evolution of our landscapes and are very helpful for the understanding of evolution processes and consequently for the design of landscape-orientated policies. Pressures upon the landscape and values of our landscapes can be defined according to their traditional characteristics; traditional landscapes can be defined as those landscapes having a distinct and recognizable structure, which reflect relations between the composing elements and have a significance for natural, cultural or aesthetical values. In most cases, such landscapes evolved slowly and took centuries to form their values. Sometimes land changes happen fast and spread in vast areas so that some agricultural or natural landscapes, widely perceived as traditional, have very recent origin. In this paper, some preliminary observation and case-studies performed on a set of historical photos are dealt with. In 1935, the Italian Land Register Department commissioned SARA company to survey Viterbo province between 1935-1938 through aerial photographs. During the survey, 5,000 photographs on glass plates were taken at a very low altitude, featuring a very high resolution. Thus, they represents a valuable source of information for documenting past and present land-use practices, local cultural heritage and changes in the landscape. Processing
\end{abstract}

Correspondence: Maria Nicolina Ripa, DAFNE, Università degli Studi della Tuscia, Via San Camillo de Lellis snc, 01100,Viterbo.

Tel. +39.0761.357362.

E-mail:nripa@unitus.it

Key words: Aerial photos, traditional landscape, landscape transformation, land use/land cover change.

(C) Copyright M.N. Ripa et al., 2013

Licensee PAGEPress, Italy

Journal of Agricultural Engineering 2013; XLIV(s2):e96

doi:10.4081/jae.2013.s2.e96

This article is distributed under the terms of the Creative Commons Attribution Noncommercial License (by-nc 3.0) which permits any noncommercial use, distribution, and reproduction in any medium, provided the original author(s) and source are credited. this set of historical photos has started, aimed to quantitatively and qualitatively analyse the 1935-1938 landscape patterns and their role in the development of nowadays landscapes.

\section{Introduction}

Changes in land use and land cover are some of the most evident effects of human activities giving rise to modern landscapes. Mainly the agricultural (cultural) landscapes showed (and are probably going to show in the future) the far reaching changes which occurred as a result of technological, socio-economic and political developments as well as global environmental change. The intensification of agricultural production, the retreat of agriculture from unfavourable sites, the processes of urbanization but also afforestation and the natural processes of secondary succession of fallow fields, have produced deeply different modern landscapes in terms of structure, functions and patterns from those pre-existing in many areas of our country and in many other European areas (Bender, 2005; Bouma, 1998, CalvoIglesias, 2009, Antrop, 2004; Van Eetvelde, 2004). Under these pushes, in many cases, changes occurred very quickly, particularly during the 20th century, often with no connection with past landscapes, but as a result of consecutive land reorganization in order to better adapt its use and spatial structure to the changing societal demands.

If landscapes changes are the natural expression of the interaction between natural and cultural forces, nevertheless changes today are often seen as a threaten for landscape integrity and for the cultural identity of population.

These concerns are expressed in the European Landscape Convention (ELC) which highlights two fundamental issues, among the others: i) the importance of landscape as an expression of cultural and natural heritage of a population (“... recognize landscapes in law as an essential component of people's surroundings, an expression of the diversity of their shared cultural and natural heritage, and a foundation of their identity" Art. 5, a), and ii) the need of implementing landscape policies “....aimed at protection, management and planning through the adoption of specific measures"(Art 5, b).

A historical perspective is desirable for the comprehension of landscape origin and transformation and for the identification of traditional landscapes. Some authors define traditional landscapes as those one which evolved during centuries (Antrop, 1997), but, according to the ELC, the cultural significance of some landscapes and the link with population must be considered too. Some landscapes can have a recent origin but they can represent the history of a population. It is also desirable to identify and implement those landscape policies invoked by ELC for landscape protection in a perspective of sustainability, but tradition and sustainability (considering its comprehensive meaning), not always overlap (Bouma, 1998; Carmona, 2010; Antrop, 2005; Angelstam, 2013, Puddu et al, 2009; Vos, 1999; Recanatesi, 2010; Antrop, 2006). 
Actually the ELC is aimed “... to promote landscape protection, management and planning, and to organize European co-operation on landscape issues", but does not suggest methods or criteria to be adopted.

The detection of land use/land cover change and the consequent analysis of landscape dynamics has become more and more important and it is fundamental to comprehend the genesis of nowadays landscapes.

The production of thematic maps, representing both actual and past conditions, is a main issue in understanding landscape dynamics as well as natural and anthropogenic processes (Pelorosso, 2009).

Aerial photographs represent an important source of information about landscapes of the past, being the main existent database providing high detailed evidence of landscape changes .. In 1935, the Italian Land Register Department commissioned the survey of the whole Viterbo province (352,000 hectares) through aerial photographs. This material, forgotten for a long period, was recently re-discovered and moved to the Viterbo State Archive.

This is by far the oldest Italian example (and one of the oldest in the world) of a large aerial-photograph survey systematically covering a wide, continuous region. Furthermore, the photos were taken at a very low altitude, thus featuring a very high resolution. Thus, they are an invaluable resource to study the historical development of cultural and natural landscapes in C-Italy. A project aiming at digitalizing, orthorectifying and geo-referencing this huge set of historical photos has recently started, in order to quantitatively and qualitatively analyse the landscape patterns of 1935-1938 and their role in the development of present-day landscapes.

This paper presents a still in progress work, whose purpose is the establishment of a province scale diachronic information system focused on the landscape dynamic and evolution allowing cultural and environmental evaluation. It will collect information on the territory coming from aerial photographs, historical maps (Catasto Gregoriano) and archive documents related to the Riforma Fondiaria of 1951. A Web-Catalogue of one century of landscape evolution in the Province of Viterbo is going to be implemented. It can represent an important source of memory for scientists, land planners, and local administrations.

This web catalogue will allow to analyse landscape in terms of biodiversity variation through the last century, or in terms of effectiveness of agricultural policies on agricultural development, or in terms of effectiveness of land planning on nowadays landscape.

\section{Material and methods}

In the period between 1935 and 1938, on behalf of the Ministry of Finance (Direzione generale del Catasto e dei Servizi Tecnici), S.A.R.A. (Società per Azioni Rilevamenti Aerofotogrammetrici), established in 1921 by Umberto and Amedeo Nistri, started an aerial survey aimed to produce new cadastral maps with the photogrammetric method that could update the Pontifical cadaster still in use after the unification of Italy 1860 (Figure 1). (Scardozzi).

For this purpose Airplanes of the "Ala Littoria S.A.", established by the fascist regime annexing in 1934 several private company, were used. The aircrafts were equipped with a machine Nistri AFL7 (AFL92) with a Goerz-Geodar F/7.7 lens having a 199, $8 \mathrm{~mm}$ focal length. Stereoscopic sequences (consisting in pairs of images of the same area taken from different angles), taken with an angle of 6 degrees have been realized.

In order to obtain final maps at a scale 1:2000, the flight altitude was fixed at 1600-1800 $\mathrm{m}$ for images taken on rural areas, and 800-1000 m for urban areas.

8 seconds and 4 seconds were the shooting intervals for rural and urban areas, with a flight speed of $150 \mathrm{Km} / \mathrm{h}$.
The so-called "Fondo Nistri" is constituted by approximately 7.000 aerial photographs on glass plate $13 \times 18 \mathrm{~cm}$ at a scale of about 1:10.000/1:11.000 (Figure 2). No date is reported on the plate, but, from the examined documents, it emerges that the survey started in the southern part of the province of Viterbo in May 1935 and ended in 1938. Most of the photos were taken in winter because the absence of foliage made it easier the identification of boundaries between the fields. Photograms in the same stripe present an overlay rate ranging from 25 to $45 \%$, parallel adjacent stripes shows an overlay of about $55-70 \%$ often resulting redundant (Figure 3 ). This great quantity of images has been very profitable in the phase of image processing, since during the time, some photographic plates have been damaged or corrupted and the presence of different shooting of the same area anyway allowed, in most cases, a complete reconstruction of land cover.

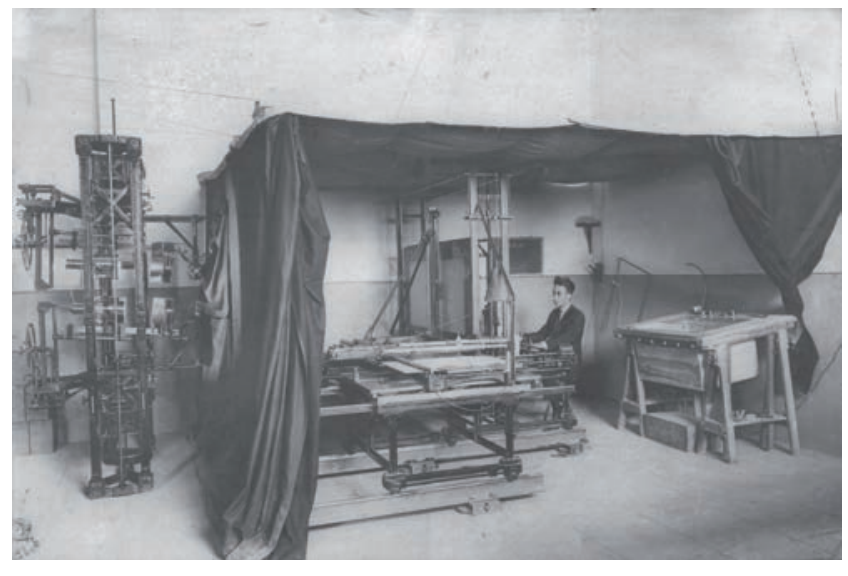

Figure 1. Laboratory of SARA Nistri.

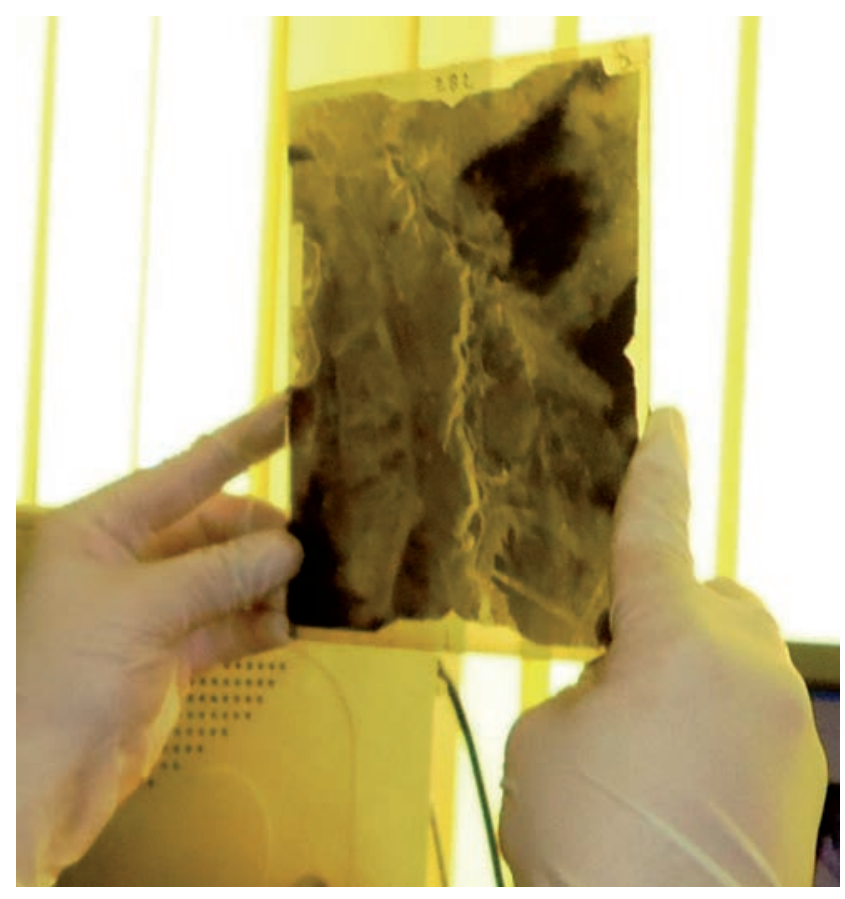

Figure 2. A glass plate of "Fondo Nistri". 


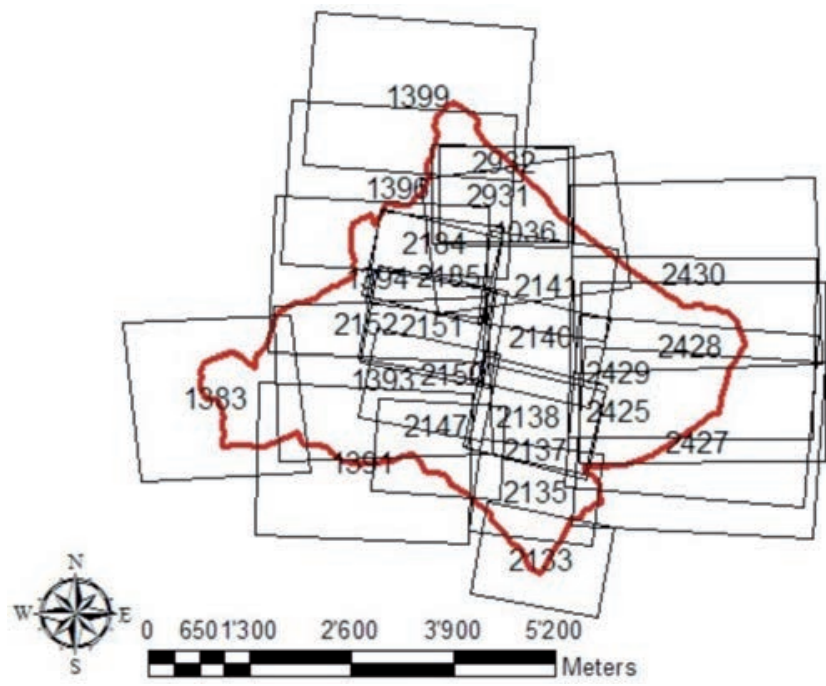

Figure 3. An example of the scheme of photographic shooting.

The experimental survey covered the whole territory of the province of Viterbo and it represents a unique document. It allows the reconstruction of land use/land cover in 1935-40 capturing an image of our country preceding the deep important changes occurred during the twentieth century. This huge material has never been inventoried, probably for the outbreak of the Second World War, and its inventory and cataloguing represents one of the goals of the project.

Each glass plate needs to be scanned with an appropriate scanner for transparent glass with low positional error adopting a resolution of 1600 dpi which preserves the resolution of the photos. Great care must be put in handling the glass plate to protect the emulsion covering the impressed side of the glass plate. The scanned images are processed and orthorectified in order to correct the deformations due to the characteristics of the camera and to the relief. The procedure proposed for the landscape dynamics analysis consists of six sequential steps: (1) Aerial photos orthorectification; (2) Orthophotosradiometric correction; (3) Orthophotos mosaicking; (4) Photo interpretation and land cover map building, and (5) land cover change analysis (Gennaretti et al., 2011).

The accuracy of the orthorectification process has been verified by the RMSE (Root Mean Square Error) index applied on the GCP position.

In most cases, while all land cover classes were easier to distinguish in the 2010 ortho-photos, in the historical ones some cover classes were hard to detect due to their monochrome greyscale, the winter shooting and the condition of the glass plate. Macro classes have been found out with a thematic resolution which, at this phase of the work, can change according to the characteristics of the different areas.

Photo interpretation has been firstly performed for the recent images (2010); subsequently, this base layer has been updated with the photos taken in 2010 and in 1935 . This procedure allows to minimize the errors of change detection (sliver polygons and spurious changes, Genaretti et al., 2011). The obtained land use maps have been compared with present land use to point out the landscape dynamics, which can be the starting point for further analysis and considerations.

Image processing and analysis have been performed using the software ArcGis (ESRI) and Orthoengine (PCI Geomatica).
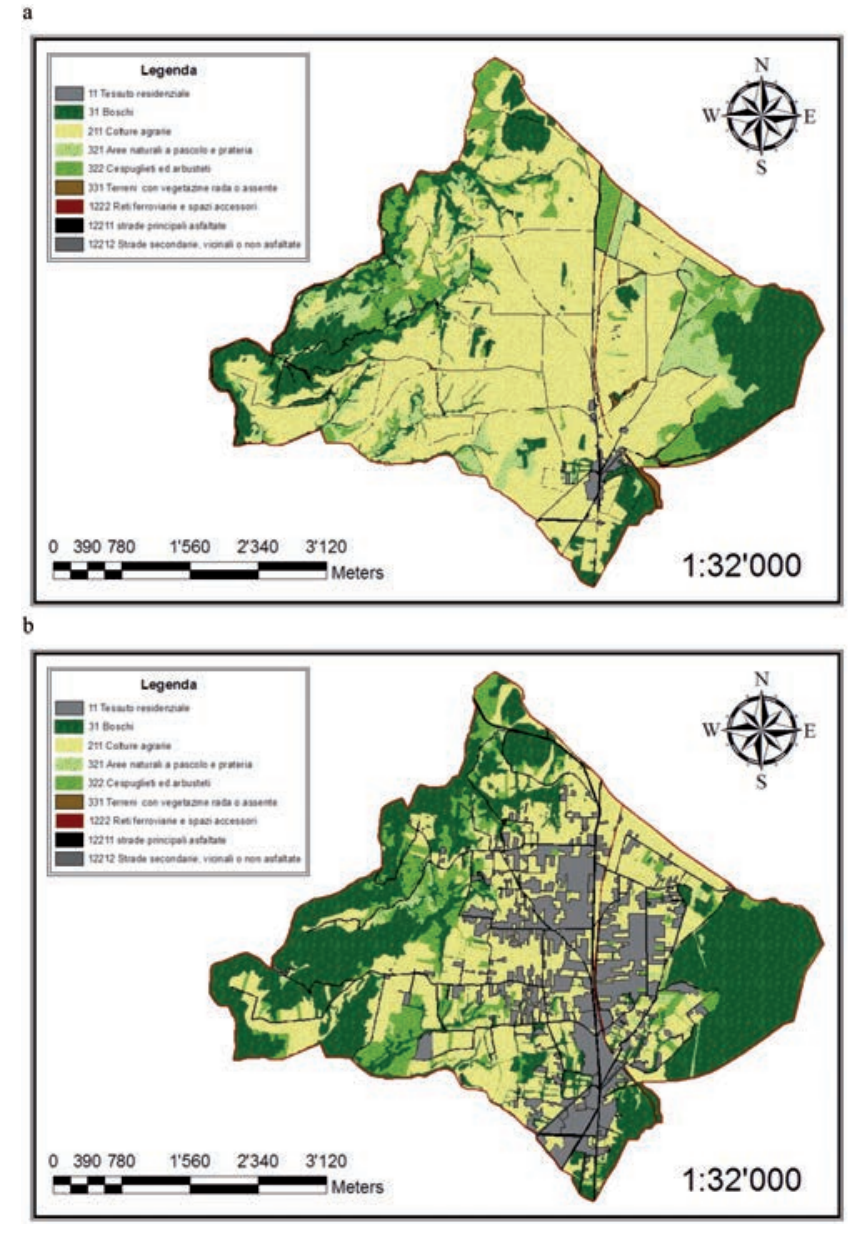

Figure 4. Land use in the municipality of Oriolo Romano a) 1936, b) 2010.

\section{Results and discussion}

Although the work is going to be carried out on the whole territory of the province of Viterbo, in this paper preliminary results concerning some selected areas are presented.

The selected areas are Oriolo Romano, Vitorchiano, Canino and Barbarano Romano. Ortho-rectification accuracy gave satisfactory results in all the processed images; in most cases the ground $\mathrm{X}$ and $\mathrm{Y}$ RMSE were found to be lower than $3 \mathrm{~m}$.

\section{Oriolo Romano}

In this area the aerial photos were taken during the winter of 1936; the photo interpretation allowed the identification of 9 types of land use that have been used also for the map of 2010 (Figure 4; Table 1). The comparison between the land use maps of 1938 and 2010 shows: a loss of agricultural areas that evolve either into shrublands due to abandonment, or into urban areas. The relevant growth of urban areas occurred mainly with detriment of agricultural areas and, to a very lesser extent, of natural and semi-natural areas; the expansion of the town follows the path of the main road network (Table 2; Figure 5). 
Table 1. Oriolo Romano - Land use in 1936 and 2010.

\begin{tabular}{|c|c|c|c|c|}
\hline Land use & $1936(\mathrm{Ha})$ & $2010(\mathrm{Ha})$ & Change (Ha) & Change (\%) \\
\hline Agricultural & 1065,84 & 656,93 & $-408,90$ & $-38,36$ \\
\hline Wood & 422,40 & 695,96 & 273,57 & 64,76 \\
\hline Urban areas & 14,60 & 306,82 & 292,23 & 2002,22 \\
\hline Natural grassland & 164,12 & 33,47 & $-130,65$ & $-79,61$ \\
\hline Bushes and shrubs & 190,04 & 178,39 & $-11,65$ & $-6,13$ \\
\hline Areas with rare vegetation cover & 8,02 & 0,00 & $-8,02$ & $-100,00$ \\
\hline Main roads & 13,43 & 16,69 & 3,26 & 24,25 \\
\hline Secondary roads & 36,85 & 26,86 & $-9,99$ & $-27,11$ \\
\hline Railway networks and ancillary areas & 5,01 & 5,16 & 0,15 & 2,95 \\
\hline
\end{tabular}

Table 2. Oriolo Romano - Transition matrix 1936 - 2010.

\begin{tabular}{lcccccccccc}
\hline 1936 & $\begin{array}{c}\text { Areas with } \\
\text { rare } \\
\text { vegetation }\end{array}$ & $\begin{array}{c}\text { Railway } \\
\text { networks }\end{array}$ & $\begin{array}{c}\text { Main } \\
\text { roads }\end{array}$ & $\begin{array}{c}\text { Secondary } \\
\text { roads }\end{array}$ & $\begin{array}{c}\text { Natural } \\
\text { grassland }\end{array}$ & $\begin{array}{c}\text { Bushes and } \\
\text { shrubs }\end{array}$ & $\begin{array}{c}\text { Urban } \\
\text { areas }\end{array}$ & Agricultural & Wood & 2010 \\
Areas with rare vegetation cover & 0 & 161 & 0 & 0 & 190 & 4.847 & 12.730 & 26.126 & 36.117 & 80.171 \\
Railway networks & 0 & 50.137 & 0 & 0 & 0 & 0 & 0 & 0 & 0 & 50.137 \\
\hline Main roads & 0 & 0 & 131.076 & 100 & 0 & 0 & 3.137 & 0 & 0 & 134.313 \\
Secondary roads & 0 & 176 & 7.663 & 214.323 & 4.730 & 11.331 & 6.020 & 22.530 & 101.746 & 368.519 \\
\hline Natural grassland & 0 & 0 & 135 & 5.572 & 36.226 & 219.413 & 39.815 & 471.956 & 868.097 & 1.641 .215 \\
Bushes and shrubs & 0 & 0 & 5.221 & 6.411 & 94.575 & 374.159 & 66.532 & 306.127 & 1.047 .342 & 1.900 .366 \\
\hline Urban areas & 0 & 0 & 250 & 3 & 0 & 422 & 133.391 & 10.138 & 1.748 & 145.952 \\
Agricultural & 0 & 1.143 & 17.461 & 34.977 & 182.015 & 1.043 .325 & 2.738 .931 & 5.527 .536 & 1.093 .509 & 10.638 .897 \\
\hline Wood & 0 & 0 & 5.072 & 7.233 & 16.986 & 128.937 & 67.664 & 186.895 & 3.811 .203 & 4.223 .990 \\
Tot. 2010 & 0 & 51.617 & 166.879 & 268.618 & 334.721 & 1.782 .433 & 3.068 .221 & 6.551 .309 & 6.959 .762 & Tot. 1936 \\
\hline
\end{tabular}

\section{Vitorchiano}

In this area the aerial photos were taken probably during the winter of 1938; the photo interpretation allowed the identification of 3 macro-classes of land use that have been used also for the map of 2010 (Figure 6; Table $1 \mathrm{e} 2$ ). The comparison between the land use maps of 1938 and 2010 shows, also for this municipality, a relevant growth of urban areas and a reduction of agricultural areas while natural areas are substantially unchanged (Table 3; Figure 6).

Although in both cases a quite usual and widespread phenomenon can be observed, the spatial pattern of the growth of urban areas in these territories is quite different. In the territory of Vitorchiano the sprawl urbanization predominates over a compact growth of the town; this behaviour can be ascribed to the building of an important highway which crosses the territory of Vitorchiano and connects the city of Viterbo with an important railway and highway junction. Nearby the highway, the development of some residential areas quickly approachable from the town has been promoted. Nevertheless it must be noticed a spread presence of buildings also in the photos of 1938 suggesting a different settlement pattern whose origin could be sought in the history of the territory.

Although the analysis regarding the areas of Canino and Barbarano Romano are still in progress, the results coming out are very interesting. From a preliminary evaluation a trend of landscape transformation similar to the previous described and quite common in many areas of our country, can be observed. It can be summarized in an increase of urban areas, a slight increase of wood and natural areas with shrubs and bushes and a decrease of agricultural areas. Nevertheless a peculiar phenomenon emerges in both areas thanks to the information derived from the analysis of the aerial photos. In fact they provide an

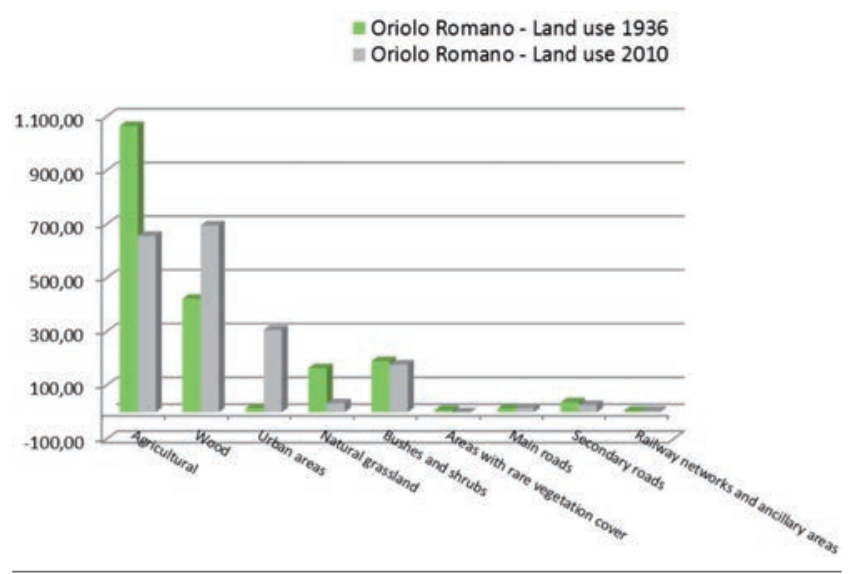

Figure 5. Oriolo Romano - comparison between land use in 1936 and 2010. 


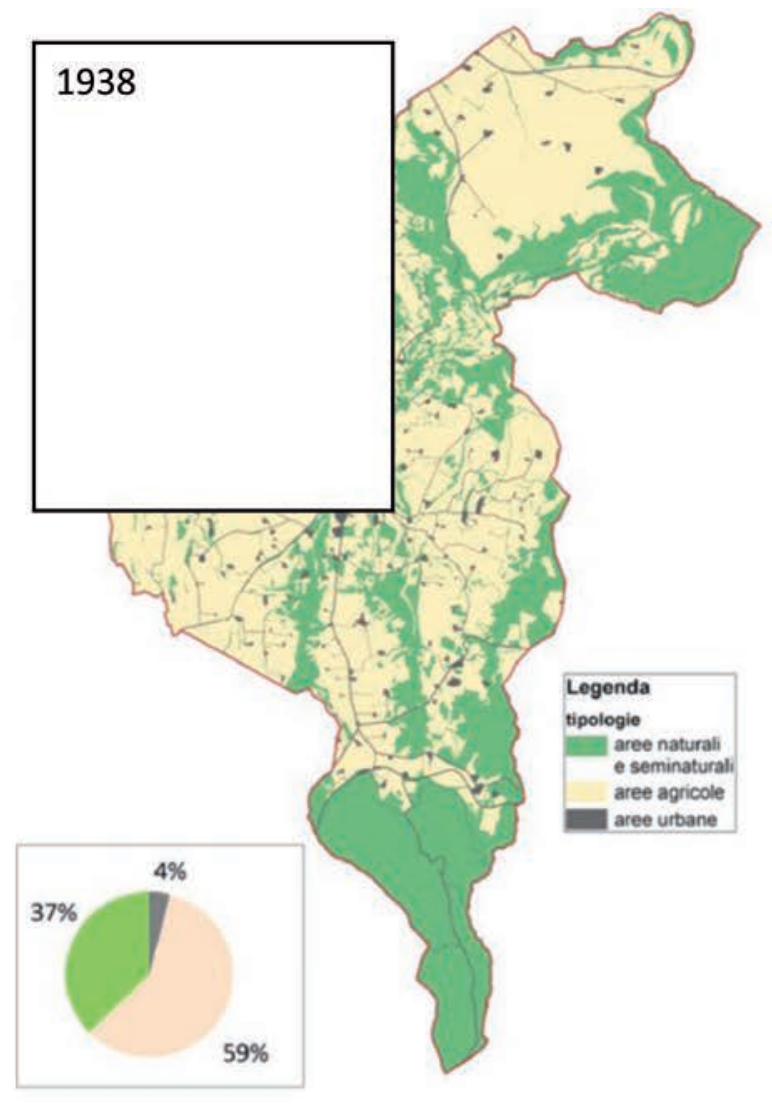

imagine of the territory preceding many important events, primarily the socio-economic changes of the 1950's - incl. the "Riforma Fondiaria" (land reclamation), which started in 1951.

In the territory of Canino olive groves presently cover $2.400 \mathrm{Ha}$, producing a good quality and typical oil. Olive groves landscape as well is considered as typical and traditional, dating back to Etruscan age. Archival sources (e.g. "Inchiesta Jacini", 1883) easily show that a hundred years ago Canino had only 300 ha of olive groves. The 1936 aerial photographs show a presence of olive groves only in the area adjacent the town and a landscape dominated by herbaceous crops and grazing land. During the 1951-1954, following the "Riforma Fondiaria" of 1950, the "Ente Maremma" planted 350.000 olive trees in the Viterbo and Grosseto provinces shaping a landscape which, from then on, would be considered "traditional” for that territory. ("...è, infatti, intendimento dell'Ente dare grande diffusione all'olivo; colline spoglie di ogni vegetazione verranno rivestite di olivi (...). Si è dovuto far ricorso in alcuni casi, oltre che alla potente attrezzatura meccanica dell'Ente, anche all'uso di esplosivi. Su terreni ove vegetava stentatamente il cespugliato, ad una anno appena di distanza dall'esproprio sono stati impiantati gli oliveti" (Ente Maremma, 1953).

For the territory of Barbarano, comparing the land cover obtained by the aerial photographs of 1936 with the present one, it can be noticed

Table 3. Vitorchiano - Land use in 1938 and 2010.

\begin{tabular}{lcccc} 
Land use & $1938(\mathrm{Ha})$ & $2010(\mathrm{Ha})$ & Change $(\mathrm{Ha})$ & Change (\%) \\
Agricultural & 1755,35 & 1465,37 & $-289,98$ & $-16,52$ \\
Urban areas & 117,89 & 454,91 & 337,02 & 285,88 \\
\hline Natural & 1112,06 & 1065,02 & $-47,04$ & $-4,23$ \\
\hline
\end{tabular}

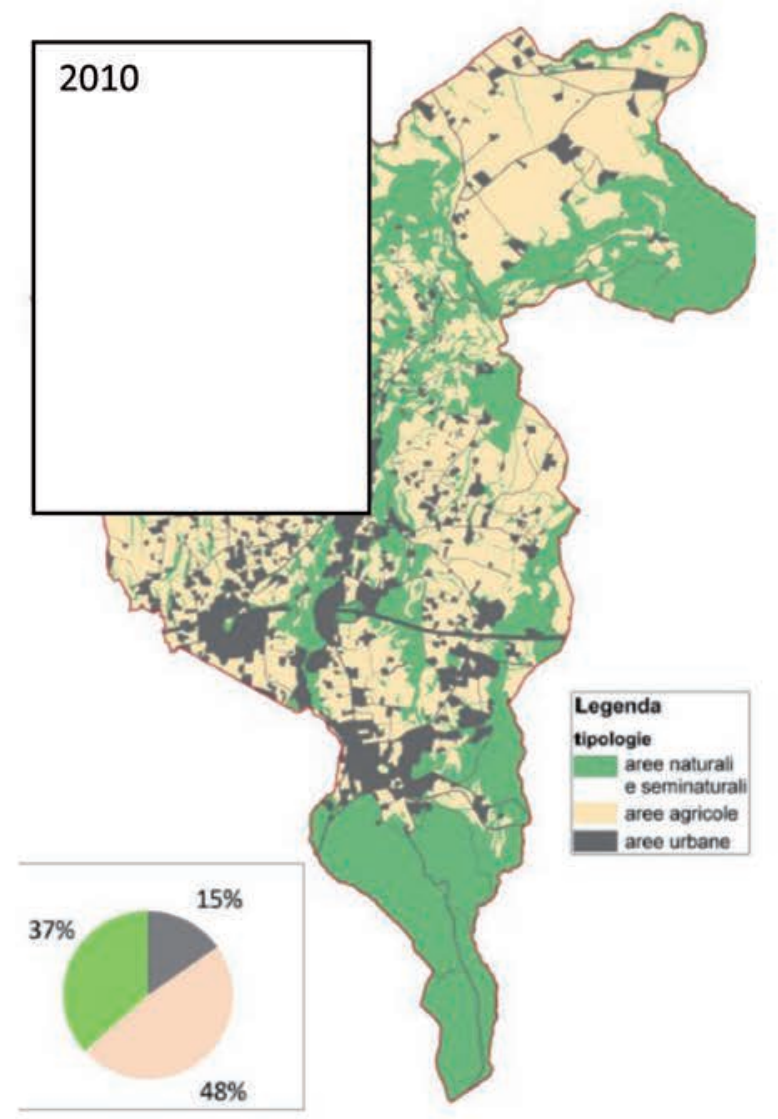

Table 4. Vitorchiano - Transition matrix 1938 - 201

\begin{tabular}{lcccc}
2010 & Agricultural & Urban areas & Natural & Total 1938 \\
$\mathbf{1 9 3 8}$ & & & & \\
Agricultural & 1356,61 & 283,81 & 114,93 & 1755,35 \\
Urban areas & 4,91 & 110,63 & 2,35 & 117,89 \\
\hline Natural & 103,85 & 60,47 & 947,74 & 1112,06 \\
Total 2010 & 1465,37 & 454,91 & 1065,02 & \\
\hline
\end{tabular}

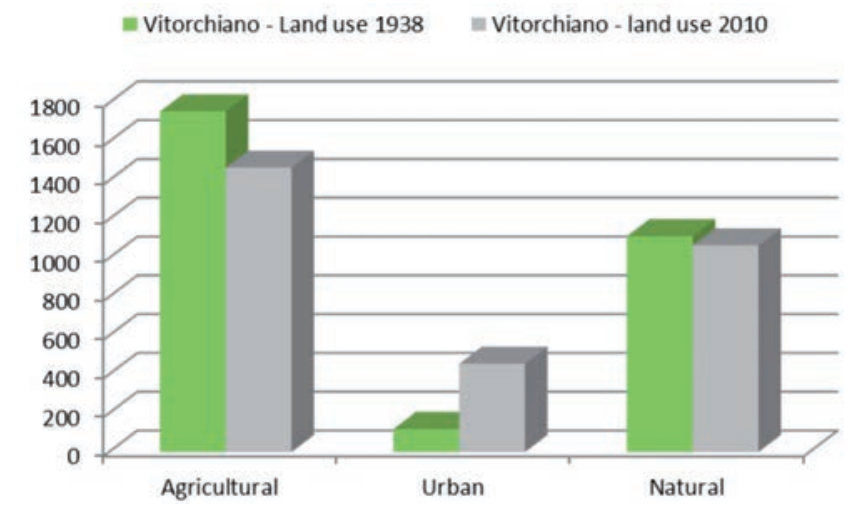

Figure 6. Land use in the municipality of Vitorchiano a) 1938, b) 2010.

Figure 7. Vitorchiano - comparison between land use in 1938 and 2010. 
an expansion of natural areas represented by shrubland and grasslands mainly in the neighboring of Tolfa Mountain with detriment of arable land. This kind of landscape is today perceived as "typical" (and actually has a very high diversity of flora and fauna showing a strong ecological significance); but it is derived from the abandonment of "Quarteria" (four-year rotation of arable and pasture).

a

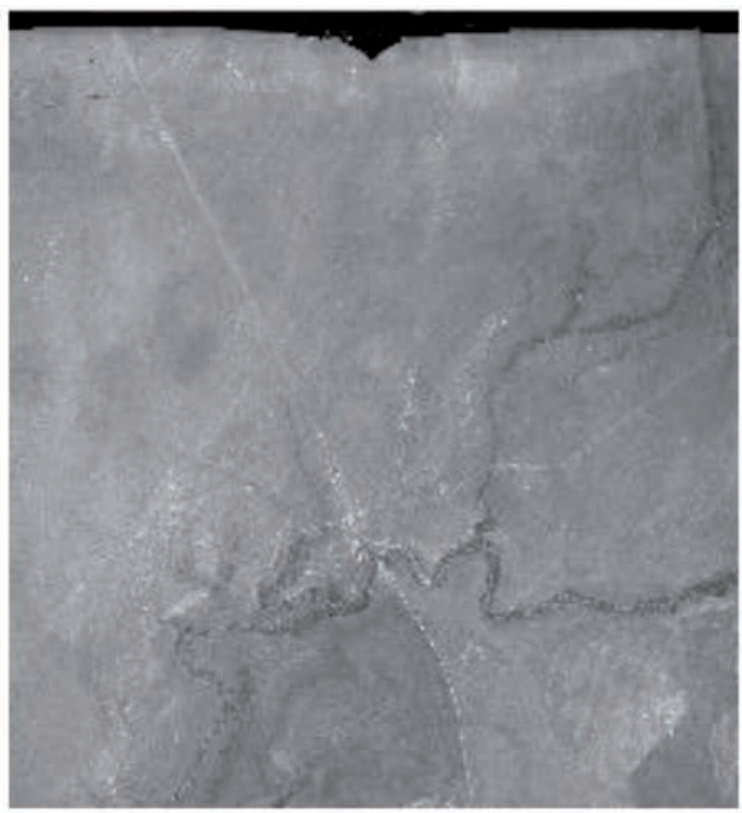

b

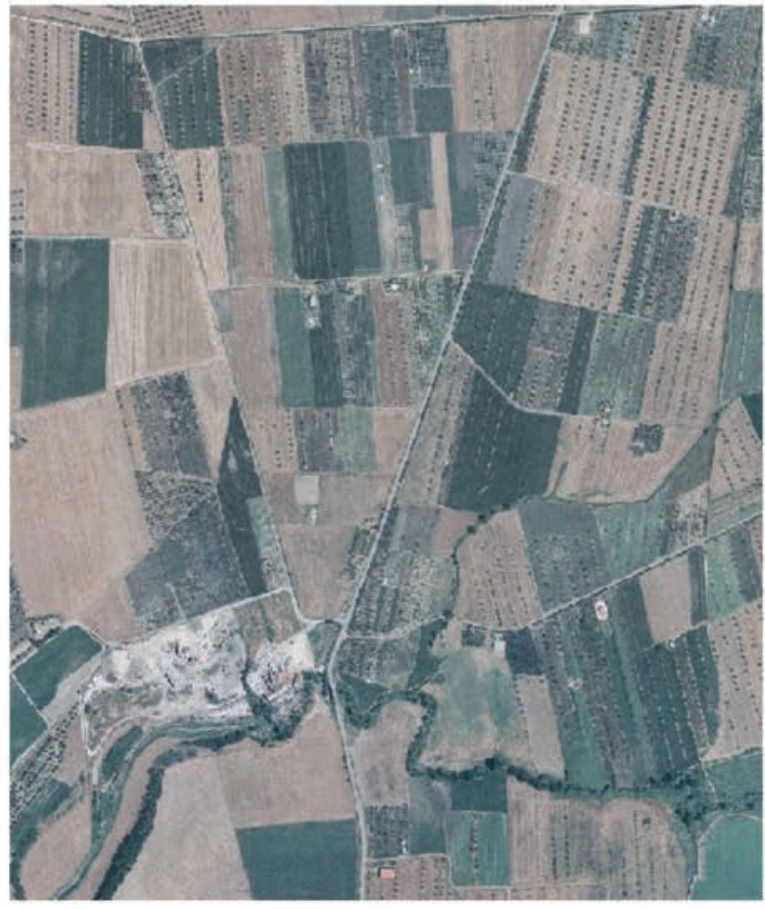

Figure 8. Aerial Photos of the municipality of Canino a) 1938, b) 2010. a
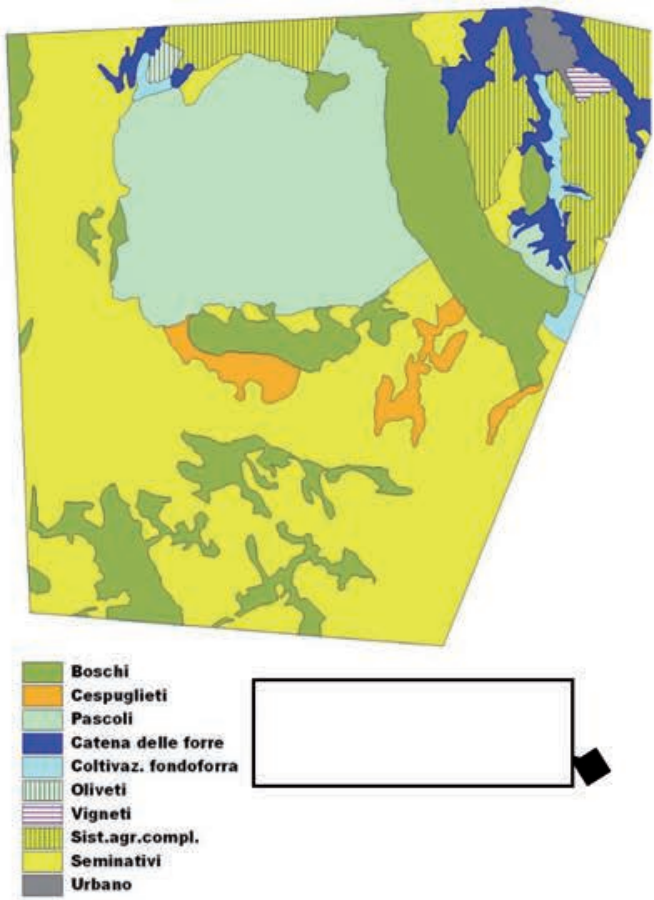

b

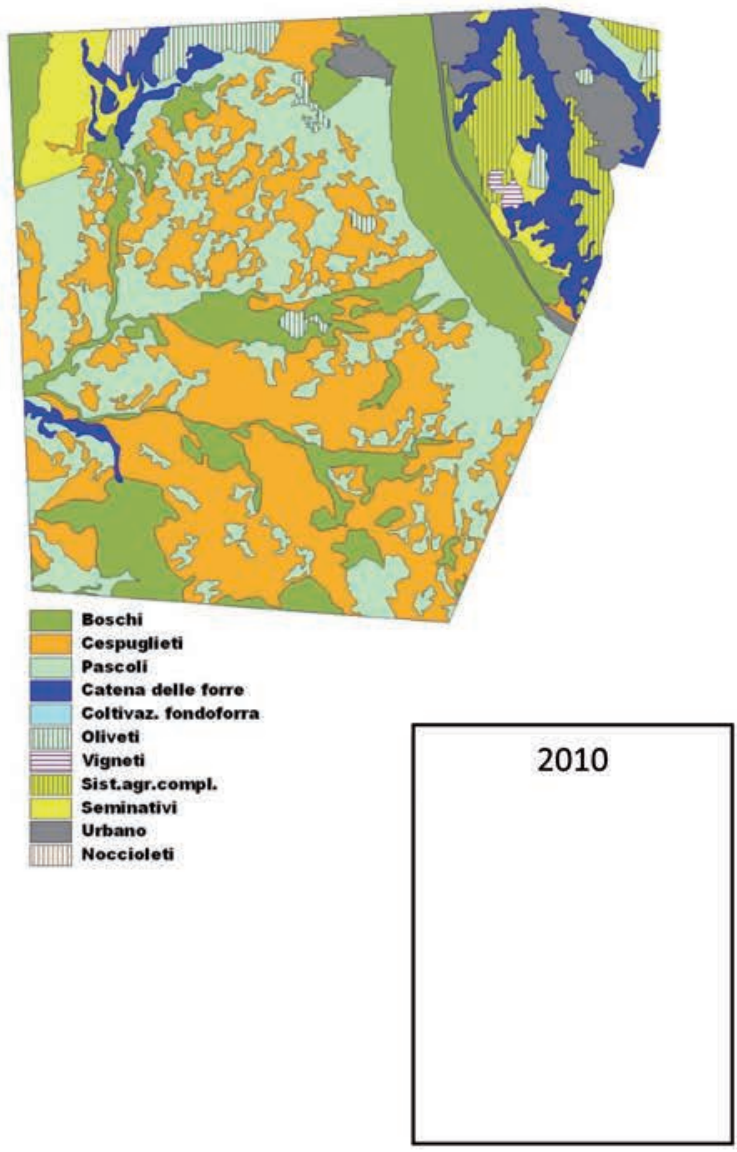

Figure 9. Land use in the municipality of Barbarano Romano a) 1936, b) 2010. 


\section{Conclusions}

The first goal of setting up a methodology for processing and analysing these old aerial photographs has been very satisfactorily achieved. It represents a first step towards the implementation of the Web Landscape Catalogue for the territory of the Viterbo Province. The preliminary results reported in the present paper, underline how the research applications of such an old (and at the same time high-resolution) collection of digitalized aerial photographs are endless. If compared with the 1954 "Volo GAI", they have a much higher resolution and quality, and they were taken before the socio-economic changes of the 1950 's - incl. the "Riforma Fondiaria" (land reclamation), which started in 1951 so that they can provide a snapshot of the whole territory before many changes in agricultural pattern and management occurred.

Compared with the 1943-44 RAF photos, they have a better resolution and a complete coverage of a broader region. The only disadvantage of the Fondo Nistri is represented by the fact that pictures were taken during the winter, making the photo interpretation and the singling out of many types of land use/land cover difficult. The adopted method (proposed in Gennaretti et al, 2011) allows to overcome this inconvenience.

Important information can be derived from these images for land planners and managers regarding the purposes of landscape management and planning. In many cases the restoration of traditional landscape is invoked considering "traditional" equal to natural. The preliminary results obtained for the territory of Canino and Barbarano provide and tickle insights concerning the origin and development of some types of landscapes that are commonly viewed as "traditional" - although historical and archival sources suggest they had a recent origin.

\section{References}

Angelstam P., Andersson K., Isacson M., Gavrilov D.V., Axelsson R., Bäckström M., Degerman E., Elbakidze M., Kazakova-Apkarimova E., Sartz L., Sädbom S., Törnblom J., (2013), Learning About the History of Landscape Use for the Future: Consequences for Ecological and Social Systems in Swedish Bergslagen, Ambio, 146159.

Antrop M., (1997), The concept of traditional landscapes as a base for landscape evaluation and planning. The example of Flanders Region, Landscape and Urban Planning 38: 105-117

Antrop M., (2004), Landscape change and the urbanization process in Europe, Landscape and Urban Planning 67: 9-26

Antrop M., (2005), Why landscape of the past are importante for the future, Landscape and Urban Planning 70: 21-34

Antrop M., (2006), Sustainable landscapes: contradiction, fiction or utopia?, Landscape and Urban Planning 75: 187-197

Baudry J., Burel F., Thenail C., Le Coeur D., (2000), A holistic landscape ecological study of the interactions between farming activities and ecological patterns in Brittany, France, Landscape and Urban Planning 50: 119-128

Bouma J., Varallyay G., Batjes N.H., (1998), Principal land use changes anticipated in Europe, Agriculture, Ecosystems and Environment 67: $103-119$

Bender 0., Boehmer H.J., Jens D., Schumacher K.P. (2005), Using GIS to analyse long-term cultural landscape change in Southern Germany, Landscape and Urban Planning 70: 111-125

Calvo-Iglesias M.S., Fra-Paleo U., Diaz-Varela R.A., (2009), Changes in farming system and population as drivers of land cover and landscape dynamics: The case of enclosed and semi-openfield systems in Northern Galicia (Spain), Landscape and Urban Planning 90: 168-177

Carmona A., Nahuelhuala L., Echeverríab C., Báezc A., (2010), Linking farming systems to landscape change: An empirical and spatially explicit study in southern Chile, Agriculture, Ecosystems and Environment 139: 40-50

Cassinis G.- Aerofotogrammetria e Catasto - Comunicazione presentata al $2^{\circ}$ Congresso Nazionale degli Ingegneri Italiani- Roma, 1931.

Gennaretti F., Ripa M. N., Gobattoni F., Boccia L., Pelorosso R. (2011). A methodology proposal for land cover change analysis using historical aerial photos. Journal of Geography and Regional Planning, 4(9): 542-556

Pelorosso R, Leone A, Boccia L (2009). Land cover and land use change in the Italian central Apennines: A comparison of assessment methods. Appl. Geogr., 29: 35-48.

Puddu G., Pelorosso R., Gobattoni F., Ripa M.N. (2010). Landscape transformations seen through the historical cartography: Sardinia as case study. Proceedings of "Forest Landscapes and Global Change-New Frontiers in Management, Conservation and Restoration" IUFR0 Landscape Ecology Working Group International Conference, September 21-27, 2010, Bragança, Portugal. J.C. Azevedo, M. Feliciano, J. Castro \& M.A. Pinto (Eds.) Instituto Politécnico de Bragança, Bragança, Portugal.

Recanatesi F., M.N. Ripa, A. Leone (2011), Landscape Change (1930 2010) in a Mediterranean Natural Reserve, Journal of Geography and Regional Planning, Vol. 4(5): 261-272, ISSN 2070-1845.

Scardozzi G. - Studi di Aerotopografia Archeologica, Archeologia Aerea 3 '8

Van Eetvelde V., Antrop M., (2004), Analyzing structural and functional changes of traditional landscapes - two examples from Southern France, Landscape and Urban Planning 67: 79-95

Vos W., Meekes H., (1999), Trends in European cultural landscape development: perspectives for a sustainable future, Landscape and Urban Planning 46: 3-14

Esperimenti di fotogrammetria aerea per la formazione delle mappe del catasto italiano- Comunicazione presentata dalla direzione generale del catasto e dei servizi tecnici alla I Riunione dell'Associazione Ottica Italiana. Firenze, 21-24 maggio 1934-XII.

Geomatica Orthoengine, User guide (2003).

PCI- Use'r Guide, Version 8.2 (2001). 